\title{
Analysis of ORM1 gene in breast cancer: is it a risk factor in Mexican population?
}

\author{
Liliana García-Ortiz ${ }^{1 *}$, José Gutiérrez-Salinas², Mariana Téllez-Araiza³ ${ }^{3}$ Mauricio González-Avante4, \\ Octavio D. Reyes-Hernández ${ }^{5}$ and Mónica Sierra-Martínez ${ }^{6}$
}

${ }^{1}$ Genomic Medicine Division; ${ }^{2}$ Laboratory of Biochemistry and Experimental Medicine, Centro Médico Nacional 20 de Noviembre, Instituto de Seguridad y Servicios Sociales de los Trabajadores del Estado (ISSSTE); ${ }^{3}$ Autoimmunity Laboratory, Instituto Nacional de Enfermedades Respiratorias; ${ }^{4}$ Blood Bank, Centro Médico Nacional 20 de Noviembre, ISSSTE; ${ }^{5}$ Laboratory of Cancer Molecular Biology, UMIEZ, Facultad de Estudios Superiores Zaragoza, Universidad Nacional Autónoma de México; ${ }^{6}$ Laboratory of Genetics and Molecular Diagnosis, Hospital Juárez de México. Mexico City, Mexico

\begin{abstract}
Introduction: ORM1 gene located on the long arm of chromosome 9 encodes for alpha-1-acid glycoprotein (AGP1), the gene contains two single nucleotide variants located in exon 1 and exon 5, which are implicated in immunosuppressive activities of AGP1, affecting the progress and clinical course of diseases such as cancer. Due to the foregoing, the objective of this study was to determine the genotypic and allelic frequency of variants c.113G>A of exon 1 and c.520G>A of exon 5 of the ORM1 gene, to evaluate their association with breast cancer (BC). Materials and methods: A case-control study was conducted, 101 patients diagnosed with adenocarcinoma of mammary gland and 104 healthy women were included. Of each participant DNA was obtained for the genotyping of 2 variants of the gene ORM1 and assesses its clinical correlation. Results: The analysis of the genotypic and allelic frequencies of the variant c.520G>A of exon 5 showed that patients with $B C$ had a higher frequency of the GG genotype compared to controls (99\% vs. $89.42 \%$; respectively). While the phenotype-genotype correlation of exon 1 showed that patients with $B C$ and GG genotype had a higher age at the time of their last calving date, compared to genotype $A A$ and $A G$ patients ( $36.44 \pm 0.83$ vs. $32.35 \pm 0.98$ and $31.44 \pm 0.83$, respectively), both results was statistically significant $(P<0.05)$. Conclusions: The polymorphisms of the gene ORM1 and its protein could intervene in $B C$ affecting the clinical course and progression of the disease.
\end{abstract}

Key words: ORM1. Single nucleotide variant. Breast cancer. AGP.

\section{Introduction}

The ORM1 gene is located on the long arm of chromosome 9 in the 31-32 (9q31-32) region. It contains 5 exons and encodes alpha-1-acid glycoprotein (AGP1), which has immunomodulatory functions such as cell inhibition (neutrophils and T lymphocytes), platelet aggregation inhibition, interleukin (IL) 2 inhibition during inflammatory processes, and IL-1 production inhibition in macrophages ${ }^{1,2}$, which are all involved in antitumor immune response.
The single nucleotide variant (SNV) c.113G>A in exon 1 of the ORM1 gene has been reported to be able to produce a phenotypic alteration in the AGP1 protein, making for it to have slow electrophoretic migration (S phenotype), which is related to a more powerful immunosuppressive function in comparison with the isoform with faster electrophoretic migration ( $F$ phenotype), encoded by exon 5 c.520G $>$ A variant of the same gene; therefore, these variants appear to be able to modulate AGP1 protein biochemical characteristics and biological

\section{Correspondence:}

*Liliana García-Ortiz

E-mail: garortiz@yahoo.com
Date of reception: 15-08-2019

Date of acceptance: 23-11-2019

DOI: 10.24875/j.gamo.M20000198
Available online: $25-05-2020$ Gac Mex Oncol. 2020;19(2):1-7 www.gamo-smeo.com license (http://creativecommons.org/licenses/by-nc-nd/4.0/). 
functions, thus affecting the progress and clinical course of diseases such as cancer ${ }^{3-8}$.

In the process of breast cancer (BC) tumorigenesis, for example, which is considered a global public health problem $^{9}$, various DNA structural alterations have been detected, which range from large chromosomal rearrangements, translocations, deletions, insertions and copy number variation to single nucleotide variants (SNV) in various genes, including the ORM1 gene 10-12. $^{\text {. }}$

In Japanese, German and Swedish populations, ORM1 gene SNVs have been described to be associated with a blockage of the antitumor immune response, thus contributing to the preservation and development of tumor cells in the mammary gland tissue $e^{1,3,4,12}$.

Consequently, various groups in the world highlight the need to study the BC genome in order to help pinpointing the biological mechanisms of cancer onset and progression, and to be able to find biomarkers that allow timely diagnosis and thus prevent $\mathrm{BC}^{10,13,14}$.

In view of the above, the purpose of this work is to determine the genotypic and allelic frequency of ORM1 gene exon $1 \mathrm{c} .113 \mathrm{G}>\mathrm{A}$ and exon $5 \mathrm{c} .520 \mathrm{G}>\mathrm{A}$ variants, which encode glycoprotein AGP1 $S$ and $F$ isoforms, in order to assess their clinical association with $B C$ in a sample of Mexican population.

\section{Material and methods}

A case-control study was carried out in the period of 2015 to 2016, which was approved by the respective research and ethics committees of the participating institutions. One-hundred and one patients referred from the oncology outpatient services of Hospital Juárez of México and National Medical Center 20 de Noviembre of the Institute of Social Security and Services of State Workers (ISSSTE - Instituto de Seguridad y Servicios Sociales de los Trabajadores del Estado), with a diagnosis of adenocarcinoma of the mammary gland confirmed by histopathological study, at any clinical stage, without a history of concomitant diseases and who, at the time the sample was obtained, had not received surgical treatment, chemotherapy or radiotherapy, were included. Disease evolution time was taken into account, which was defined as the time elapsed from the diagnosis of the disease to the moment the patient was admitted to the protocol.

In addition, 104 healthy women referred from the same above-mentioned hospitals, paired by age as controls, and who underwent a clinical interview, physical examination and biochemical analysis that included blood count, blood chemistry, lipid profile, and viral panel, which should have been confirmed as normal exams in order for them to be classified as healthy subjects, were included. All participants signed an informed consent form, and peripheral venous blood was obtained from each one of them, which was collected in a 5-ml Vacutainer ${ }^{\mathrm{TM}}$ tube with ethylenediaminetetraacetic acid for DNA extraction. Genomic DNA was obtained from leukocytes using the salting-out method ${ }^{15}$.

Exon $1 \mathrm{c} .113 \mathrm{G}>\mathrm{A}$ variant genotyping was performed by polymerase chain reaction (PCR) and automated sequencing, while exon 5 c.520G $>$ A variant determination was carried out with PCR-RFLP (restriction fragment length polymorphisms), according to García-Ortiz ${ }^{16}$.

\section{Statistical analysis}

Statistical analysis was carried out with the GraphPhad Prism ${ }^{\circledR}$ program, version 4.0 for Windows ${ }^{\circledR}$ (GraphPad Software, San Diego, CA, USA), using an Exce ${ }^{\circledR}$ database. ORM1 gene exon 1 and exon 5 SNVs genotypic and allelic frequencies, as well as Hardy-Weinberg equilibrium, were obtained from the data. The association between genetic variants and clinical characteristics was analyzed using the chisquare test for tendencies, with the confidence interval and the odds ratio $(\mathrm{OR})$ being calculated, as appropriate. Quantitative clinical characteristics were evaluated using Student's $t$-test, unpaired, with post-test Wilcoxon or ANOVA, as appropriate, and the association between variables was assessed using Spearman's coefficient. For all analyses, statistical significance was assumed with a $p$ value $<0.05$.

\section{Results}

A total of 101 patients diagnosed with $B C$ who met the inclusion criteria for this protocol and 104 healthy women as the control group were included. Average age of the $B C$ patients was $52.83 \pm 0.85$ years, while average age for the control group was $55.76 \pm 0.85$ years. Age at menarche, age at first gestation, number of pregnancies, abortions, and age at menopause averages showed no significant differences between both groups (Table 1).

To find out whether ORM1 gene exon $1 \mathrm{c} .113 \mathrm{G}>\mathrm{A}$ and exon 5 c.520G $>A$ variants, which encode AGP1 glycoprotein $S$ and $F$ isoforms, respectively, were associated with BC, a first analysis of the genotypic and allelic frequencies of these variants was carried out, which showed that they were in Hardy-Weinberg 
Table 1. General characteristics of patients with breast cancer $(\mathrm{BC})$ and those in the control group

\begin{tabular}{|l|c|c|}
\hline Parameter & $\mathrm{BC}(\mathrm{n}=101)$ & Controls $(\mathrm{n}=104)$ \\
\hline Age (years) & $52.83 \pm 0.85(28-80)$ & $55.76 \pm 0.85(25-78)$ \\
\hline Age at menarche & $12.81 \pm 0.83(10-16)$ & $12.03 \pm 0.87(11.14)$ \\
\hline Age $1^{\text {st }}$ gestation & $22.78 \pm 2.30(15-37)$ & $21.52 \pm 3.01(16-36)$ \\
\hline Gestations & $2.59 \pm 1.20(0-12)$ & $3.02 \pm 1.50(0-10)$ \\
\hline Abortions & $0.48 \pm 0.42(0-3)$ & $1.02 \pm 0.25(0-4)$ \\
\hline Age at menopause & $44.48 \pm 5.23(0-65)$ & $43.95 \pm 4.21(0-58)$ \\
\hline
\end{tabular}

All results are expressed as averages \pm standard error (range).

equilibrium (Table 2). As it can be observed, exon 1 c.113G $>A$ variant genotypic frequencies were similar for patients with $B C$ and those in the control group; in both groups, there was a higher proportion of the AG genotype, followed by AA and GG.

On the other hand, the analysis of exon 5 c.520G $>A$ variant genotypic and allelic frequencies showed that both the patients with $\mathrm{BC}$ and those in the control group had a higher frequency of the GG genotype (99 and $89.42 \%$, respectively) in comparison with genotypes GA and AA, which showed a lower proportion in both groups; however, these differences were statistically significant between the study groups: GA vs. GG (OR: 24.7; confidence interval [Cl]: 1.4-4.25; $p=0.008$ ) and $A A$ vs. GG (OR: 0.014; IC: 0-1.04; $p=0.0005)$.

Since the distribution of exon 5 genotypes was practically concentrated on genotype $G G$, both in patients with $B C$ and in the control group, only analyzing the clinicopathological characteristics in patients with $\mathrm{BC}$ and their relationship with ORM1 gene exon 1 different genotypes was considered.

When analyzing the obstetric-gynecologic characteristics divided by exon $1 \mathrm{AA}, \mathrm{AG}$ and $\mathrm{GG}$ genotypes in patients with $B C$ and in the control group, no significant difference was found between menarche, age at first gestation, number of gestations, deliveries, abortions, final menstrual period or menopause. We only found that patients with genotypes $B C$ and $G G$ were older at their last delivery, in comparison with AA and AG-genotype patients $(36.44 \pm 0.83$ vs. $32.35 \pm 0.98$ and $31.44 \pm 0.83$, respectively), with these results being statistically significant $(p<0.05)$ (Table 3$)$. The analysis of tumor histopathological characteristics, divided by genotypes, showed that patients with $\mathrm{BC}$ and the $\mathrm{AA}$ genotype had a lower average tumor size $(2.57 \pm 0.25 \mathrm{~cm})$

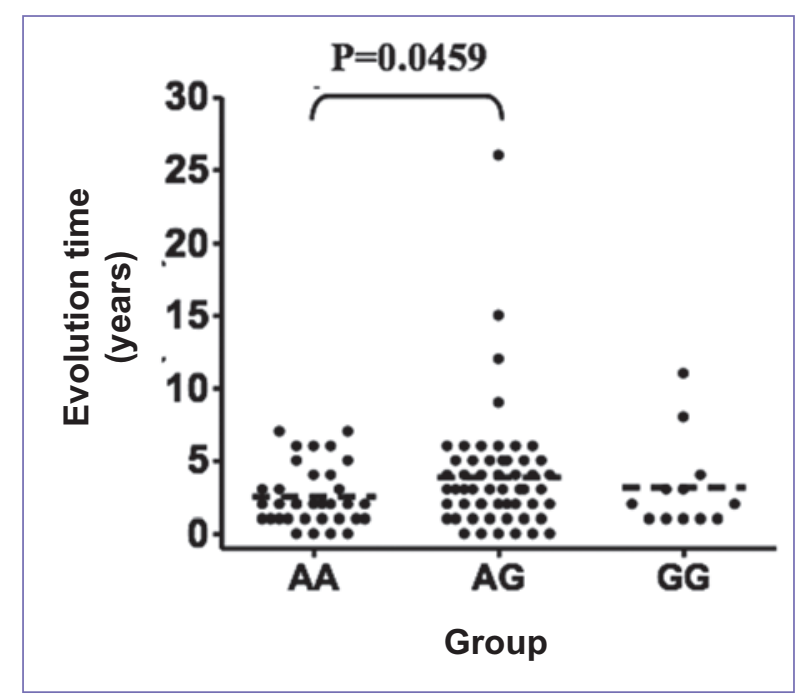

Figure 1. Disease evolution time in patients with breast cancer divided by ORM1 gene exon 1 genotype.

in comparison with those with genotypes $A G$ $(3.51 \pm 0.35 \mathrm{~cm})$ and $G G(3.18 \pm 0.46 \mathrm{~cm})$; however there were no statistically significant differences.

We could only observe a significant trend for histological subtype when the samples were triple-negative and grouped in genotype GG, as well as for the presence of metastasis and its relationship with ORM1 gene exon 1 GG genotype (Table 4).

The study of disease evolution time in the patients with $B C$, divided by $A A, A G$ and $G G$ genotypes, showed that patients with genotype $A G$ had the highest average in the type of disease evolution in comparison with patients with genotype AA $(3.9 \pm 0.6$ vs. $2.53 \pm 0.36$ years, respectively; $p<0.05)$ and genotype $G G(3.12 \pm 0.92$ years $)$ (Fig. 1).

\section{Discussion}

Our work is the first one to study, in a Mexican population, the relationship between $\mathrm{BC}$ clinical characteristics and ORM1 gene exon 1 c.113G $>A$ and exon 5 c.520G $>A$ variants, which can modify the primary structure of the protein that encodes AGP1. This protein is related to biological processes such as the acute phase response and inflammation, IL-6 and tumor necrosis factor production negative regulation, as well as neutrophil and platelet degranulation, which are all associated with antitumor response $e^{2,8,17-21}$.

In addition, these ORM1 gene variants can modify AGP1 protein functions related to drug transport, since these variables differ from each other in the drug-binding 
Table 2. ORM1 gene exon $1 \mathrm{c} .113 \mathrm{G}>\mathrm{A}$ and exon $5 \mathrm{c} .520 \mathrm{G}>\mathrm{A}$ polymorphisms genotypic and allelic frequency in patients with breast cancer $(B C)(n=101)$ and in the control group $(n=104)$

\begin{tabular}{|c|c|c|c|c|c|c|c|c|}
\hline \multirow[t]{3}{*}{ Exon $1 A / G(c .113 G>A)$} & \multirow{2}{*}{\multicolumn{2}{|c|}{$\begin{array}{c}\text { Genotype frequency } \\
n(\%)\end{array}$}} & \multirow[t]{3}{*}{ OR (95\% CI) } & \multirow[t]{3}{*}{$\mathbf{p}$} & \multirow[t]{3}{*}{ Allele } & \multirow{2}{*}{\multicolumn{2}{|c|}{$\begin{array}{c}\text { Allelic frequency } \\
n(\%)\end{array}$}} & \multirow[t]{3}{*}{$\mathbf{p}$} \\
\hline & & & & & & & & \\
\hline & BC & Controls & & & & BC & Controls & \\
\hline \multirow[t]{2}{*}{ AA } & $34(0.337)$ & $42(0.404)$ & & & & & & \\
\hline & & & $1.44(0.79-2.62)$ & N.S. & A & 0.609 & 0.634 & \\
\hline \multirow[t]{2}{*}{$A G$} & $55(0.544)$ & $47(0.452)$ & & & & & & N.S. \\
\hline & & & $0.98(0.4-2.4)$ & N.S. & G & 0.391 & 0.366 & \\
\hline GG & $12(0.119)$ & $15(0.144)$ & & & & & & \\
\hline \multicolumn{9}{|l|}{ Exon $5 \mathrm{G} / \mathrm{A}(\mathrm{c} .520 \mathrm{G}>\mathrm{A})$} \\
\hline \multirow[t]{2}{*}{ GG } & $100(0.990)$ & $93(0.894)$ & & & & & & \\
\hline & & & $24.7(1.4-4.25)$ & $<0.05$ & G & 0.99 & 0.951 & \\
\hline \multirow[t]{2}{*}{ GA } & $0(0.000)$ & $11(0.106)$ & & & & & & $<0.05$ \\
\hline & & & $0.014(0-1.04)$ & $<0.05$ & A & 0.01 & 0.049 & \\
\hline AA & $1(0.010)$ & $0(0.000)$ & & & & & & \\
\hline
\end{tabular}

All groups were at Hardy-Weinberg equilibrium.

$\mathrm{OR}=$ odds ratio; $\mathrm{Cl}$ : confidence interval; N.S. = non-significant

Table 3. Obstetric-gynecological characteristics in patients with $\mathrm{BC}$, divided by ORM1 gene exon 1 genotype

\begin{tabular}{|c|c|c|c|c|c|}
\hline Variable & AA $(n=34)$ & $A G(n=55)$ & $G G(n=12)$ & Genotype comparison & p-value \\
\hline Menarche (age) & $12.94 \pm 0.28(10-16)$ & $12.78 \pm 0.16(10-16)$ & $12.78 \pm 0.16(10-16)$ & $\begin{array}{l}A A \text { vs. } A G \\
A A \text { vs. } G G \\
A G \text { vs. } G G\end{array}$ & $\begin{array}{l}0.591 \\
0.494 \\
0.603\end{array}$ \\
\hline Age $1^{\text {st }}$ gestation & $21.53 \pm 0.88(16-37)$ & $21.75 \pm 1.12(0-36)$ & $21.75 \pm 1.12(0-36)$ & $\begin{array}{l}A A \text { vs. } A G \\
A A \text { vs. } G G \\
A G \text { vs. } G G\end{array}$ & $\begin{array}{l}0.078 \\
0.495 \\
0.608\end{array}$ \\
\hline Gestations (n) & $4.18 \pm 0.43(1-13)$ & $3.35 \pm 0.32(0-15)$ & $3.345 \pm 0.32(0-15)$ & $\begin{array}{l}A A \text { vs. } A G \\
A A \text { vs. } G G \\
A G \text { vs. } G G\end{array}$ & $\begin{array}{l}0.277 \\
0.932 \\
0.392\end{array}$ \\
\hline Parous (n) & $2.97 \pm 0.45(0-12)$ & $2.15 \pm 0.28(0-11)$ & $2.15 \pm 0.28(0-11)$ & $\begin{array}{l}A A \text { vs. } A G \\
A A \text { vs. } G G \\
A G \text { vs. } G G\end{array}$ & $\begin{array}{l}0.521 \\
0.562 \\
0.222\end{array}$ \\
\hline Abortions (n) & $0.5 \pm 0.15(0-3)$ & $0.51 \pm 0.12(0-3)$ & $0.51 \pm 0.12(0-3)$ & $\begin{array}{l}A A \text { vs. } A G \\
A A \text { vs. } G G \\
A G \text { vs. } G G\end{array}$ & $\begin{array}{l}0.963 \\
0.545 \\
0.525\end{array}$ \\
\hline LD (age) & $32.35 \pm 0.98(24-41)$ & $31.44 \pm 0.83(20-48)$ & $36.44 \pm 1.48(31-46)$ & $\begin{array}{l}A A \text { vs. } A G \\
A A \text { vs. } G G \\
A G \text { vs. } G G\end{array}$ & $\begin{array}{l}0.4916 \\
<0.05 \\
<0.05\end{array}$ \\
\hline FMP (age) & $45.32 \pm 0.84(33-54)$ & $44.73 \pm 0.80(26-59)$ & $44.73 \pm 0.80(26-59)$ & $\begin{array}{l}A A \text { vs. } A G \\
A A \text { vs. } G G \\
A G \text { vs. } G G\end{array}$ & $\begin{array}{l}0.626 \\
0.117 \\
0.076\end{array}$ \\
\hline Menopause (age) & $45.63 \pm 1.02(35-62)$ & $47.11 \pm 1.05(26-65)$ & $47.11 \pm 1.05(26-65)$ & $\begin{array}{l}A A \text { vs. } A G \\
A A \text { vs. } G G \\
A G \text { vs. } G G\end{array}$ & $\begin{array}{l}0.335 \\
0.506 \\
0.961\end{array}$ \\
\hline
\end{tabular}


Table 4. Tumor histopathological characteristics in patients with breast cancer, divided by ORM1 gene exon 1 genotypes

\begin{tabular}{|c|c|c|c|c|c|c|}
\hline Variables & $\mathrm{AA}(\mathrm{n}=34)$ & $A G(n=55)$ & $G G(n=12)$ & Genotypes & OR (95\% CI) & $\mathbf{p}$ \\
\hline *Tumor size $(\mathrm{cm})$ & $2.57 \pm 0.25(0.5-5)$ & $3.51 \pm 0.35(0.9-14)$ & $3.18 \pm 0.46(1-6)$ & $\begin{array}{l}A A \text { vs. } A G \\
A A \text { vs. } G G \\
A G \text { vs. } G G\end{array}$ & $\begin{array}{l}0.72(0.30-1.70) \\
1.03(0.42-2.23) \\
0.97(0.39-2.37)\end{array}$ & $\begin{array}{l}0.45 \\
0.94 \\
0.94\end{array}$ \\
\hline $\begin{array}{l}\text { Histological subtype (\%) } \\
\text { Luminal A } \\
\text { Luminal B } \\
\text { Triple-negative }\end{array}$ & $\begin{array}{l}23.5 \\
17.7 \\
58.8\end{array}$ & $\begin{array}{c}25 \\
21.9 \\
53.1\end{array}$ & $\begin{array}{c}0 \\
20 \\
80\end{array}$ & $\begin{array}{l}A A \text { vs. } A G \\
A A \text { vs. } G G \\
A G \text { vs. } G G\end{array}$ & $\begin{array}{c}0.79(0.20-3.04) \\
2.80(0.20-157.11) \\
3.52(0.30-32.54)\end{array}$ & $\begin{array}{l}0.93 \\
0.73 \\
0.52\end{array}$ \\
\hline $\begin{array}{l}\text { Stage (\%) } \\
\text { I } \\
\text { II } \\
\text { III } \\
\text { IV }\end{array}$ & $\begin{array}{c}8.8 \\
38.2 \\
53 \\
0\end{array}$ & $\begin{array}{c}12.7 \\
52.7 \\
29.1 \\
5.5\end{array}$ & $\begin{array}{c}8.3 \\
41.7 \\
50 \\
0\end{array}$ & $\begin{array}{l}A A \text { vs. } A G \\
A A \text { vs. } G G \\
A G \text { vs. } G G\end{array}$ & $\begin{array}{c}0.45(0.12-1.98) \\
0.98(0.22-4.27) \\
2.9(0.11-7.1)\end{array}$ & $\begin{array}{l}0.12 \\
0.97 \\
0.45\end{array}$ \\
\hline $\begin{array}{l}\text { Metastasis (\%) } \\
\text { Yes } \\
\text { Local } \\
\text { Distant } \\
\text { No }\end{array}$ & $\begin{array}{c}91.2 \\
0 \\
8.8\end{array}$ & $\begin{array}{c}81.8 \\
5.5 \\
12.7\end{array}$ & $\begin{array}{c}91.7 \\
0 \\
8.3\end{array}$ & $\begin{array}{l}A A \text { vs. } A G \\
A A \text { vs. } G G \\
A G \text { vs. } G G\end{array}$ & $\begin{array}{c}0.84(0.35-2.0) \\
2.53(0.63-10) \\
3(0.8-11.2)\end{array}$ & $\begin{array}{l}0.7 \\
0.18 \\
0.09\end{array}$ \\
\hline
\end{tabular}

*The results are presented as averages \pm standard error (ranges).

active site, which ultimately affects the clinical course of diseases such as $\mathrm{BC}^{2,8,17-21}$.

In regions of northern Sweden, this gene's exon 1 c.113G $>A$ variant $G G$ genotype has been reported to be significantly more frequent in patients with $B C$ in comparison with the control group of the same geographic area. Similar results are obtained for the population of southern Germany in different types of cancer, including $\mathrm{BC}^{3,22}$. However, in our study, the genotypes of this variant are similarly distributed between patients with $\mathrm{BC}$ and the control group.

Regarding the clinical parameters associated with exon 1 variants, there is in general sparse information in the literature. However, when BC and its relationship with genetic variants is studied, we must take into account factors such as age and obstetric-gynecological history (age at first gestation, number of gestations, deliveries, abortions, etc.) in the analysis, since these variables have been described to be able to increase pro-inflammatory proteins plasma concentration and/or change the gene expression of proteins related to the immune response, thus favoring and/or hindering the presence of long-term antitumor mechanisms ${ }^{23-25}$.

Thus, our study shows that patients with $\mathrm{BC}$ and exon $1 \mathrm{GG}$ genotype were older at their last delivery, which possibly indicates that this variant might be increasing AGP1 protein plasma concentration, thus favoring its immunomodulatory activity during disease progression.
On the other hand, studies of exon 5 c.520G $>A$ variant in subjects of European, American and Asian ancestry, show that GG is the predominant genotype ${ }^{26}$, just as it occurred for the Mexican population. This distribution is difficult to explain; however we speculate that the phenomenon might be part of a gene drift, where one of the alleles has been fixed or extinguished, which in general causes a decrease in genetic variability in the human population.

Our study also shows that, in patients with $\mathrm{BC}$, exon 5 GG genotype, which encodes AGP1 protein F1 isoform, is predominantly significant with regard to genotypes GA, AA of the same group, as well as to the control group genotypes. Therefore, in our population, exon 5 GG variant ( $F 1$ isoform) could be associated with cancer, conversely to the observations published for the European population, in which although exon 5 GG variant is also predominant, exon $1 \mathrm{c} .113 \mathrm{G}>\mathrm{A}$ variant (i.e., $\mathrm{S}$ isoform) appears to be associated with cancer, given that it is more immunosuppressive than isoform $\mathrm{F}^{3,4}$.

These discrepant results may be determined by the ethnic differences of the studied populations. In Mexico, miscegenation historical backgrounds have been described since the viceroyalty period; new secondary groups emerged from the coexistence of the three main primary ethnic groups (indigenous populations, Spaniards and African descendants), creating a vast miscegenation. 
Therefore, knowing the genetic variability of this and other variants that occur in our population will allow establishing the biological bases in order to understand their relationship with diseases and influence on their prognosis ${ }^{27}$.

The ORM1 gene has various genetic variants, which could act as target sites for microRNA and regulate ORM1 gene expression ${ }^{28}$, since some studies published in proteomics report the relationship between the AGP1 protein and the prognosis of patients with $\mathrm{BC}^{29}$, as well as the correlation that exists between this protein and the different clinical stages of cancer ${ }^{7,17,30,31}$.

Due to the above, we consider that one limitation of our study is, then, the lack of correlation between ORM1 gene genotype and phenotype (defined by AGP1 serum levels in patients with $B C$ ), in addition to how these different genotypes could be influencing the effectiveness of chemotherapy and overall survival rate; therefore longitudinal studies that allow us solving these so far existing uncertainties will have to be carried out.

As we can observe, ORM1 gene variants could intervene in $\mathrm{BC}$, affecting the clinical course and progression of the disease ${ }^{8,29}$. However, future studies in different populations, which help us link these variants with $\mathrm{BC}$ clinical characteristics, will be necessary.

Thus, the variants of both the ORM1 gene and its AGP1 protein appear to be potential components of a biological signaling network in conditions such as cancer, and studying them could therefore serve for the follow-up, prognosis, and treatment of patients with $\mathrm{BC}^{18,28,32-34}$.

\section{Conclusions}

Our study shows that, in patients with $B C$, exon 5 c.520G $>A$ variant GG genotype (AGP1 protein $F$ isoform) is more frequent in comparison with genotypes GA and $A A$, and it is therefore more immunosuppressive than the other genotypes, conversely to data published for other regions of the world, where exon 1 c.113G $>$ A variant (AGP1 protein $S$ isoform) is claimed to be more immunosuppressive than isoform $\mathrm{F}$.

\section{Conflict of interests}

The authors declare that they have no conflicts of interest.

\section{Acknowledgements}

Dr. Liliana García Ortiz expresses her gratitude to CONACYT (Fondo Sectorial en Salud; Proyecto salud 2012-01-181582) and the ISSSTE Scientific and
Technological Research Program (code E015) for their support for the performance of this study. In addition, our appreciation to all the women who voluntarily participated in the study.

\section{References}

1. Luo Z, Lei H, Sun Y, Liu X, Su DF. Orosomucoid, an acute response protein with multiple modulating activities. J Physiol Biochem. 2015;71(2):329-40.

2. Hochepied T, Berger FG, Baumann H, Libert C. 凶1-Acid glycoprotein: an acute phase protein with inflammatory and immunomodulating properties. Cytokine Growth Factor Rev. 2003;14(1):25-34.

3. Mittermüller J, Weidinger S. Genetic study of orosomucoid by isoelectric focusing and immunoprinting in patients with carcinoma. Electrophoresis. 1992;13(9-10):785-6.

4. Fan C, Stendahl U, Stjernberg N, Beckman L. Association between orosomucoid types and cancer. Oncology. 1995;52(6):498-500.

5. Balmaña M, Giménez E, Puerta A, Llop E, Figueras J, Fort E, et al. Increased $\alpha 1-3$ fucosylation of $\otimes-1$-acid glycoprotein (AGP) in pancreatic cancer. J Proteomics. 2016;132:144-54.

6. Ferens-Sieczkowska M, Kratz EM, Kossowska B, Passowicz-Muszyńska E, Jankowska R. Comparison of haptoglobin and alpha $\square$-acid glycoprotein glycosylation in the sera of small cell and non-small cell lung cancer patients. Postepy Hig Med Dosw (Online). 2013;67:828-36.

7. Hashimoto S, Asao T, Takahashi J, Yagihashi $Y$, Nishimura T, Saniabadi AR, et al. Alpha1-acid glycoprotein fucosylation as a marker of carcinoma progression and prognosis. Cancer. 2004;101(12):2825-36.

8. Fan C, Nylander PO, Stendahl U, Thunell M, Beckman L. Synergistic interaction between ORM1 and $\mathrm{C} 3$ types in disease associations. Exp Clin Immunogenet. 1995;12(2):92-5.

9. Reynoso-Noverón N, Villaseñor-Navarro $Y$, Hernández-Ávila M, Mohar-Betancourt A. Carcinoma in situ e infiltrante identificado por tamizaje mamográfico oportunista en mujeres asintomáticas de la Ciudad de México. Salud Públ Méx. 2013;55(5):469-77.

10. Li J. Novel methods in the study of the breast cancer genome: Towards a better understanding of the disease of breast cancer. J Cancer Ther. 2012;3:797-809.

11. Mitrunen K, Sillanpää $P$, Kataja V, Eskelinen M, Kosma VM, Benhamou S, et al. Association between manganese superoxide dismutase (MnSOD) gene polymorphism and breast cancer risk. Carcinogenesis. 2001;22(5):827-9.

12. Yuasa I, Umetsu K, Vogt U, Nakamura H, Nanba E, Tamaki N, et al. Human orosomucoid polymorphism: molecular basis of the three common ORM1 alleles, ORM1*F1, ORM1*F2, and ORM1*S. Hum Genet. 1997;99(3):393-8

13. Banerji S, Cibulskis K, Rangel-Escareno C, Brown KK, Carter SL, Frederick $\mathrm{AM}$, et al. Sequence analysis of mutations and translocations across breast cancer subtypes. Nature. 2012;486(7403):405-9.

14. Goncalves R, Warner WA, Luo J, Ellis MJ. New concepts in breast cancer genomics and genetics. Breast Cancer Res. 2014;16(5):460.

15. Miller SA, Dykes DD, Polesky HF. A simple salting out procedure for extracting DNA from human nucleated cells. Nucleic Acids Res. 1988;16(3):1215.

16. García-Ortiz L, Vargas-Alarcón G, Fragoso JM, Granados J, Maldonado Noriega L, Navas Pérez A, et al. Genet Mol Res. 2008;7(1):7-15.

17. Ayyub A, Saleem M, Fatima I, Tariq A, Hashmi N, Musharraf SG. Glycosylated Alpha-1-acid glycoprotein 1 as a potential lung cancer serum biomarker. Int J Biochem Cell Biol. 2016;70(Jan):68-75.

18. Patwa TH, Zhao J, Anderson MA, Simeone DM, Lubman DM. Screening of glycosylation patterns in serum using natural glycoprotein microarrays and multi-lectin fluorescence detection. Anal Chem. 2006;78(18):6411-21.

19. Paterson SC, Lim CK, Smith KD. Analysis of the interaction between alpha-1-acid glycoprotein and tamoxifen and its metabolites. Biomed Chromatogr. 2003;17(2-3):143-8.

20. ORM1 orosomucoid 1 [ Homo sapiens (human) ] [Internet]. Bethesda, MD EE.UU.: National Center for Biotechnology Information (NCBI), U.S. National Library of Medicine [fecha última actualización: 5 de agosto de 2018]. Disponible en: https://www.ncbi.nlm.nih.gov/gene/5004

21. Marcucci G, Perrotti D, Caligiuri MA. Understanding the molecular basis of imatinib mesylate therapy in chronic myelogenous leukemia and the related mechanisms of resistance. Commentary re: A. N. Mohamed et al., The effect of imatinib mesylate on patients with Philadelphia chromosome-positive chronic myeloid leukemia with secondary chromosomal aberrations. Clin Cancer Res.,9: 1333-1337, 2003. Clin Cancer Res. 2003;9(4):1248-52.

22. Duché JC, Herve F, Tillement JP. Study of the expression of the genetic variants of human $\otimes 1$-acid glycoprotein in healthy subjects using isoelectric focusing and immunoblotting. J Chromatogr. 1998;715(1):103-9. 
23. Reference SNP (rs) Report. rs2636890 [Internet]. Johns Hopkins University: The OMIM® database 2018. NCBI dbSNP Short Genetic Variations [fecha de consulta: 5 de octubre de 2018]. Disponible en: https://www. ncbi.nlm.nih.gov/SNP/snp_ref.cgi?type=rs\&rs=2636890

24. Ignjatovic V, Lai $C$, Summerhayes $R$, Mathesius $U$, Tawfilis $S$, Perugini MA, Monagle P. Age-related differences in plasma proteins: how plasma proteins change from neonates to adults. PLoS One. 2011; 6(2):e17213.

25. Lund E, Nakamura A, Snapkov I, Thalabard JC, Olsen KS, Holden L, et al. Each pregnancy linearly changes immune gene expression in the blood of healthy women compared with breast cancer patients. Clin Epidemiol. 2018;10:931-40.

26. Milan-Mattos JC, Anibal FF, Perseguini NM, Minatel V, Rehder-Santos P Castro $\mathrm{CA}$, et al. Effects of natural aging and gender on pro-inflammatory markers. Braz J Med Biol Res. 2019;52(9):e8392.

27. López-Beltrán C, García-Deister V. Aproximaciones científicas al mestizo mexicano. Hist Cienc Saude - Manguinhos. 2013;20(2):391-410

28. Gao X, Yang J, Wang M, Zhang J. TCF21 genetic polymorphisms and breast cancer risk in Chinese women. Oncotarget. 2016;7(34): 55757-64.
29. Smith KD, Behan J, Matthews-Smith G, Magliocco AM. Alpha-1-acid glycoprotein (AGP) as a potential biomarker for breast cancer. En: Petrescu S, editor. Glycosylation. Croacia: InTech; 2012. pp. 201-222.

30. Hanada K, Yamanaka E, Yamamoto N, Minami H, Kawai S, Sasaki Y, et al. Effects of surgery and chronic disease states on the concentrations and phenotype distribution of $\alpha 1$-acid glycoprotein: studies in patients with breast cancer and patients with chronic inflammatory disease. Int J Clin Pharmacol Ther. 2011;49(7):415-21.

31. Uslu C, Taysi S, Akcay F, Sutbeyaz MY, Bakan N. Serum free and bound sialic acid and alpha-1-acid glycoprotein in patients with laryngeal cancer. Ann Clin Lab Sci. 2003;33(2):156-9.

32. Yuasa I, Nakamura H, Umetsu K, Irizawa Y, Henke L, Henke J. The structure and diversity of alpha1-acid glycoprotein/orosomucoid gene in Africans. Biochem Genet. 2006;44(3-4):145-60.

33. Alexander H, Stegner AL, Wagner-Mann C, Du Bois GC, Alexander S, Sauter ER. Proteomic analysis to identify breast cancer biomarkers in nipple aspirate fluid. Clin Cancer Res. 2004;10(22):7500-10.

34. Hervé $F$, d'Athis $P$, Tremblay D, Tillement JP, Barré J. Glycosylation study of the major genetic variants of human $\triangle 1$-acid glycoprotein and of their pharmacokinetics in the rat. J Chromatogr B. 2003;798(2):283-94. 